\title{
Short -term outcome of off pump versus on pump coronary artery bypass grafting
}

\begin{abstract}
Ahmed Mohammed Abdo Ismaiel ${ }^{1}$ MSc; Elhusseiny Elhusseiny Gamil ${ }^{1}$ MD; Khaled Mohammed Farrag
\end{abstract} Abd El-Rahman ${ }^{2}$ PhD, Mohamed Hossiny Mohamoud Abd El-Wahab ${ }^{1}$ PhD.

* Corresponding Author:

Ahmed Mohammed Abdo Ismaiel surgeryforall@yahoo.com

Received for publication October 24, 2021; Accepted February 4, 2022; Published online February 4, 2022.

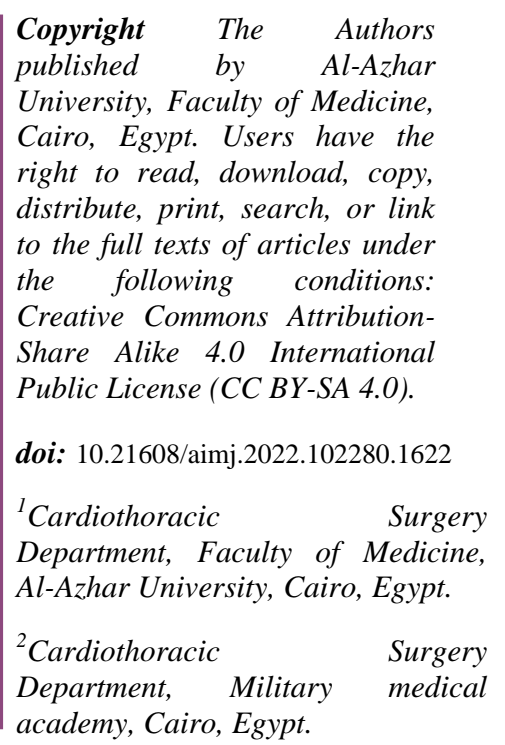

\section{INTRODUCTION}

The most frequent adult cardiac surgery procedure implemented worldwide is coronary artery bypass grafting (CABG), which is also the cornerstone of our profession. ${ }^{I}$

One of the most controversial topics in cardiac surgery is whether coronary artery bypass grafting achieved without cardiopulmonary bypass or cardioplegia is preferable to bypass grafting conducted when the heart in a chemical-arrest state with the use of the heart-lung machine. ${ }^{2}$

Off-pump coronary artery bypass grafting surgery (conducted on a beating heart) was designed to reduce perioperative problems associated with cardiopulmonary bypass and aortic cross clamping. ${ }^{3}$

The current widely used procedure of surgical coronary artery revascularization was developed and
Disclosure: The authors have no financial interest to declare in relation to the content of this article. The Article Processing Charge was paid for by the authors.

Authorship: All authors have a substantial contribution to the article.

adopted around 40 years ago, and it has since become the standard of care. The success of this method in comparison to percutaneous coronary procedures has grasped the attention of many publications in recent years. $^{4}$

Hemodynamic instability complicates off-pump coronary artery bypass grafting (OPCABG), which may lead to many organ dysfunctions, especially in patients with a low LV ejection fraction (LVEF $35<$ $\%)^{5}$

\section{PATIENTS AND METHODS}

This prospective randomized trial was pursued with a sample of 120 patients with stable coronary artery disease who received elective CABG without any concomitant surgical interventions at El Hussein and MKH Hospitals between August 2017 and September 2019. 
Patients were divided to two equal groups: Off-pump and On-pump.

After receiving informed consent from each patient, as well as confirmation from our Department Council and Local Ethical Committees, the study was carried out.

Inclusion criteria: adult patients of both gender undergoing an elective coronary artery bypass graft whom CABG was justified by coronary angiographic investigations and preoperative echocardiography.

Exclusion criteria:

Re-do patients.

Recent myocardial infarction $<6$ weeks

Patients with associated coronary and other pathology requiring combined procedure.

Patients exhibited significant carotid artery stenosis that needs surgery.

Patients refusing to participate in the study.

In all patients, a comprehensive history was taken, with asking about previous MI, or PCI and determination of patient's NYHA classification. After thorough physical examination, comprehensive laboratory testing, chest x-ray, ECG, and echocardiogram were reviewed.

Simpson's approach was used to calculate ejection fraction using $2 \mathrm{D}$ transthoracic echocardiography.

In Off-pump group: standard midline sternotomy incision was deployed for heart exposure; left internal mammary artery and right great saphenous vein were harvested simultaneously, and deep pericardial sutures were performed after incision of the pericardium. Anticoagulation was achieved using heparin, the activated clotting time was conserved above 250 seconds and the heart stabilization was secured using stabilizer (octopus). LIMA was anastomosed to LAD initially in most cases according to collateralized and collateralizing artery, then saphenous vein grafts were anastomosed to obtuse marginal branches, diagonals, and the RCA territory. This was followed by finishing proximal anastomosis, assessment of graft patency by TTFM flow and pressure, good hemostasis, and finally closure of the layers after insertion of chest tubes.

In On-pump group: standard midline sternotomy incision was deployed for heart exposure; left internal mammary artery and right great saphenous vein harvested; heparin was utilized for achieving anticoagulation; the activated clotting time was conserved above 480 seconds. CPB was instituted with a single right atrial cannula and ascending aorta cannula; moreover, myocardial protection via cardioplegia was fulfilled either by ante-grade warm blood or ante-grade cold crystalloid. Saphenous vein grafts were anastomosed to obtuse marginal branches, diagonals, RCA territory. Finally, LIMA was anastomosed to LAD and coming off $\mathrm{CPB}$. This was followed by proximal anastomosis, assessment of graft patency by TTFM flow and pressure, removal of venous and arterial cannula, good hemostasis, and finally closure of the layers after insertion of chest tubes.

Anesthetic management procedures were the same in both groups - induction and maintenance of general anesthesia with endotracheal intubation.

The following intra-operative data were collected: operative time in minutes, number of distal grafts as total and per each patient, type and number of proximal anastomosis, graft distribution territory, need for cardiac inotropes, need for IABP, transfusion of blood components, bleeding, use of D/C shock and graft patency assessment by TTFM.

Dramatic conversion to on-pump in off-pump group was assessed; meanwhile, specific parameters (aortic cross clamp time, bypass time, types of preservation cardioplegia) were assessed in on-pump group

Echocardiography was done 1 day prior to surgery then rechecked six months postoperatively to measure the ejection fraction, degree of mitral valve regurgitation, and regional wall motion abnormality.

Total CK, CKMB and cardiac troponin I levels were measured for each patient 6 hours, 12 hours, and 24 hours post-surgery.

The primary end point was early outcome including the success rate, morbidity follow-up of (MI, Arrhythmia, and Cerebrovascular stroke, renal failure requiring dialysis, Hepatic impairment, and wound infection), while secondary end points were ICU stay, ventilation time in hours and hospital stays.

Patients' follows-up was conducted after six months post operatively by NYHA, ECG, ECHO and MSCT angiography for assessment of graft patency.

\section{Statistical analysis}

IBM Statistical Package for the Social Sciences (SPSS) software (SPSS Inc., Chicago, IL, USA) was adopted for the statistical analysis. Presentation of quantitative data included mean and range, while the data were compared by independent t-test or MannWhitney test. Qualitative data are expressed as number and percentage; they were compared by Chi-square test or Fisher's exact test. $\mathrm{P}<0.05$ was deemed statistically significant.

\section{RESULTS}

The analyzed groups' demographic data, risk factors for heart diseases, and cardiac parameters revealed no significant differences. (Table 1).

Cardiac functions were assessed by echocardiography (ejection fraction (EF \%), degree of mitral regurgitation, and regional wall motion abnormality. SWMA significantly improved 
postoperatively after six months in both groups. In off-pump group, the patients had an EF\% with a mean of 61(55-69), while in on-pump group displayed a mean of 62.5(54-71) $(\mathrm{p}<0.001)$ as show in (Figure 1, Table 2).

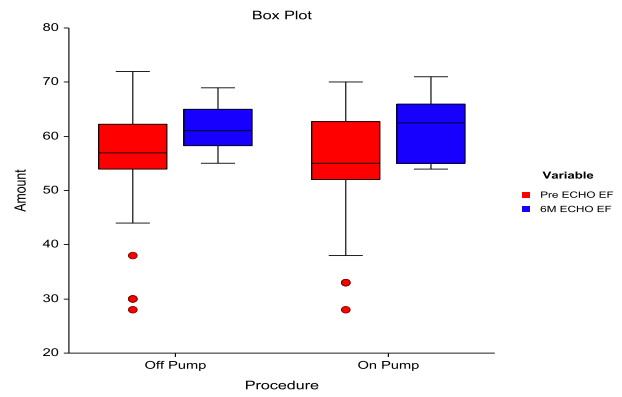

Fig 1: Box-plot diagram compares pre and post operative range of EF percentage; each box have upper and the bottom line to reflect the 75th \& 25th percentile respectively; the line across each box denotes the median. Whiskers represent the range between the minimum and maximum values with exclusion of both outliers (rounded markers) and extreme observations (asterisks).

Intraoperative parameters: operative time, need for cardiac inotropes, use of D/C shock and blood transfusion (packed RBCs, other blood components), and graft patency assessment by TTFM were recorded. Patients who underwent off-pump CABG had less mean operative time $(p<0.01)$, while the need for cardiac inotropes, use of D/C shock, blood transfusion were significantly large in on-pump group unlike Off-pump group $(\mathrm{p}<0.01)$ (Table 3$)$.

On the other hand, the off-pump group considerably required more TTFM than the on-pump group ( $\mathrm{p}$ 0.01 ), whereas TTFM values were substantially lower in the on-pump groups in comparison to the off-pump group $(\mathrm{p}<0.01)$ (Table 4$)$.

TTFM flow readings showed statistically significant difference in favor of the off-pump group compared to on-pump group as the following: LIMA to LAD, SVG to OM, SVG to RCA, and SVG to PDA. Likewise, TTFM flow readings of SVG to D were deemed significant hence it was higher in off-pump group compared to on-pump group (p 0.017) .

On the other hand, the following TTFM pressure index readings were significantly low in off-pump group compared to on-pump group: in LIMA to LAD $(\mathrm{p}<0.01)$, SVG to D, (p 0.002), SVG to OM (p 0.001) (Table 4).

\begin{tabular}{|c|c|c|c|c|}
\hline $\begin{array}{ll}\text { Parameters } & \text { Groups } \\
\end{array}$ & $\begin{array}{l}\text { Off-pump Group } \\
\text { No }=60\end{array}$ & $\begin{array}{l}\text { On-pump Group } \\
\text { No=60 }\end{array}$ & Test & P Value \\
\hline Age (years) & $\begin{array}{l}59 \\
(38-77)\end{array}$ & $\begin{array}{l}59 \\
(38-77)\end{array}$ & 0.4 & 0.516 \\
\hline $\begin{array}{ll}\text { Gender } & \text { Males } \\
& \text { Females }\end{array}$ & $\begin{array}{l}37(61.7 \%) \\
23(38.3 \%)\end{array}$ & $\begin{array}{l}35(58.3 \%) \\
25(41.7 \%)\end{array}$ & 0.1 & 0.709 \\
\hline BMI & $26(19-35)$ & $24(18-34)$ & 0.7 & 0.388 \\
\hline Dyslipidemia & $25(41.7 \%)$ & $24(40 \%)$ & 0.01 & 0.853 \\
\hline Systemic hypertension & $52(86.7 \%)$ & $43(71.7 \%)$ & 4.1 & 0.043 \\
\hline Diabetes mellitus & $48(80 \%)$ & $42(70 \%)$ & 1.6 & 0.206 \\
\hline Smoking history & $29(48.3 \%)$ & $29(48.3 \%)$ & 0.01 & 0.999 \\
\hline $\begin{array}{ll}\text { NYHA class } & \text { II } \\
& \text { III }\end{array}$ & $\begin{array}{l}30(50 \%) \\
30(50 \%)\end{array}$ & $\begin{array}{l}37(61.7 \%) \\
23(38.3 \%)\end{array}$ & 1.7 & 0.198 \\
\hline
\end{tabular}

Table 1: Clinical-demographic data in both groups, Quantitative data were expressed as Median (range) and compared using Mann Whitney test, while qualitative data were expressed as numbers and percentages and compared using Chi-square X2 test.

\begin{tabular}{|c|c|c|c|c|}
\hline $\begin{array}{ll}\text { Parameters } & \text { Groups }\end{array}$ & $\begin{array}{l}\text { Off-pump } \\
\text { No }=60\end{array}$ & $\begin{array}{l}\text { On-pump } \\
\text { No }=60\end{array}$ & Test & P Value \\
\hline \multicolumn{5}{|l|}{ Preoperative } \\
\hline $\mathrm{EF}(\%)$ & $57(28-72)$ & $55(28-70)$ & 0.1 & 0.699 \\
\hline Mild MVR (\%) & $8(13.3 \%)$ & $12(20 \%)$ & 1 & 0.327 \\
\hline Mild SWMA (\%) & $9(15 \%)$ & $9(15 \%)$ & 0.01 & 0.999 \\
\hline \multicolumn{5}{|l|}{ Postoperative $6 \mathrm{~m}$} \\
\hline $\mathrm{EF}(\%)$ & $61(55-69)$ & $62.5(54-71)$ & -6.9 & $<0.001$ \\
\hline
\end{tabular}

Table 2: Echocardiographic parameters of studied cases. Quantitative data were expressed as Median (range) and compared using Mann Whitney test, while categorized data were expressed as numbers and percentages and compared using Chi-square $\mathrm{X} 2$ test, $\mathrm{EF}=$ Ejection fraction, $\mathrm{MVR}=$ Mitral valve regurgitation, and $\mathrm{SWMA}=\mathrm{Systolic}$ regional wall motion abnormality. 


\begin{tabular}{|c|c|c|c|c|}
\hline Parameters $\quad$ Groups & $\begin{array}{l}\text { Off. Group } \\
\mathrm{No}=60\end{array}$ & $\begin{array}{l}\text { On. Group } \\
\mathrm{No}=60\end{array}$ & $\begin{array}{l}\text { Chi- } \\
\text { Square } \\
\text { Test }\end{array}$ & P Value \\
\hline Operative time in minutes & $186.5(140-300)$ & $242.5(190-335)$ & 70.6 & $<0.01$ \\
\hline Need for cardiac inotropes & $6(10 \%)$ & $35(58.3 \%)$ & 31.2 & $<0.01$ \\
\hline Use of $\mathrm{D} / \mathrm{C}$ shock & $2(3.3 \%)$ & $23(38.3 \%)$ & 22.3 & $<0.01$ \\
\hline \multicolumn{5}{|l|}{ Blood transfusion } \\
\hline Packed RBCs & $8(13.3 \%)$ & $50(83.3 \%)$ & 58.9 & $<0.01$ \\
\hline Other blood components & $14(23.3 \%)$ & $55(91.7 \%)$ & 57.3 & $<0.01$ \\
\hline Use of pacemaker & $2(3.3 \%)$ & $2(3.3 \%)$ & 0.03 & 0.855 \\
\hline Use of IABP & $4(6.7 \%)$ & $6(10 \%)$ & 0.4 & 0.509 \\
\hline
\end{tabular}

Table 3: Intraoperative parameters of studied cases. Quantitative data were denoted as Median (range) and underwent comparison using Mann Whitney test, while qualitative data were expressed as numbers and percentages and compared using Chi-square X2 test.

\begin{tabular}{|c|c|c|c|c|}
\hline Groups & $\begin{array}{l}\text { Off. Group } \\
\text { No= } 60\end{array}$ & $\begin{array}{l}\text { On Group } \\
\text { No=60 }\end{array}$ & $\begin{array}{l}\text { Chi-Square } \\
\text { Test }\end{array}$ & P Value \\
\hline \multicolumn{5}{|l|}{ TTFM Revised grafts } \\
\hline by flow $<20 \mathrm{ml} / \mathrm{min}$ & $25(41.7 \%)$ & $13(21.7 \%)$ & 5.5 & 0.019 \\
\hline by pressure Index > 5 & $25(41.7 \%)$ & $13(21.7 \%)$ & 5.5 & 0.019 \\
\hline TTFM readings flow $(\mathrm{ml} / \mathrm{min})$ & & & MV-Test & \\
\hline LIMA to LAD & $58(34-110)$ & $34(24-77)$ & 53 & $<0.01$ \\
\hline LIMA to D & $39(34-43)$ & $31(27-33)$ & 5 & 0.025 \\
\hline SVG to LAD & $40(32-53)$ & $31.5(27-39)$ & 2.6 & 0.109 \\
\hline SVG to D & $32(21-67)$ & $28(22-35)$ & 5.7 & 0.017 \\
\hline SVG to OM & $45(29-87)$ & $33(29-43)$ & 39.8 & $<0.01$ \\
\hline SVG to RCA & $46(33-65)$ & $29(23-36)$ & 17.4 & $<0.01$ \\
\hline SVG to PDA & $42(29-54)$ & $32(25-44)$ & 20.6 & $<0.01$ \\
\hline \multicolumn{5}{|l|}{ TTFM readings Pressure index } \\
\hline LIMA to LAD & $2(1-3)$ & $2(1-4)$ & 19.3 & $<0.01$ \\
\hline LIMA to D & $3(2-3)$ & $3(2-4)$ & 0.5 & 0.491 \\
\hline SVG to LAD & $2.5(2-4)$ & $3(2-3)$ & 0.1 & 0.714 \\
\hline SVG to D & $2(1-3)$ & $3(2-4)$ & 9.4 & 0.002 \\
\hline SVG to OM & $2(1-4)$ & $2(2-3)$ & 11.2 & 0.001 \\
\hline SVG to RCA & $2(2-3)$ & $2(2-3)$ & 0.3 & 0.598 \\
\hline SVG to PDA & $2(1-3)$ & $2(1-3)$ & 0.01 & 0.855 \\
\hline
\end{tabular}

Table 4: graft patency assessment by TTFM among studied cases. Quantitative data were expressed as Median (range) and compared using Mann Whitney test, while qualitative data were expressed as numbers and percentages and compared using Chi-square $\mathrm{X} 2$ test.

In terms of myocardial damage markers $(\mathrm{CK}, \mathrm{CK}$ $\mathrm{MB}$, and troponin I), the off-pump group's troponin I levels were considerably lower at 6,12 , and 24 hours following the surgery than the on-pump group ( $\mathrm{p}$ 0.002).

Mechanical ventilation duration and elevated liver enzymes were significantly greater in the on-pump group compared to the off-pump group $(\mathrm{p}<0.01)$.

The length of ICU stay was also significantly longer in the on-pump group compared to the off-pump group.

Accordingly, the mean ICU stay in the on-pump group was 60(37-90) hours, compared to 36(32-80) hours in the off-pump group $(\mathrm{p}<0.001)$.

In terms of postoperative MI, stroke, arrhythmia, and renal failure that requires dialysis, there were no statistically significant differences between the two groups.

In the current study, no patient needed examination owing to bleeding (Table 5).

Regarding to the follow-up of NYHA Score and comparing it with baseline NYHA Score, the difference was statistically significant between the two groups (P-value < 0.001) (Figure 2, Table 6). 


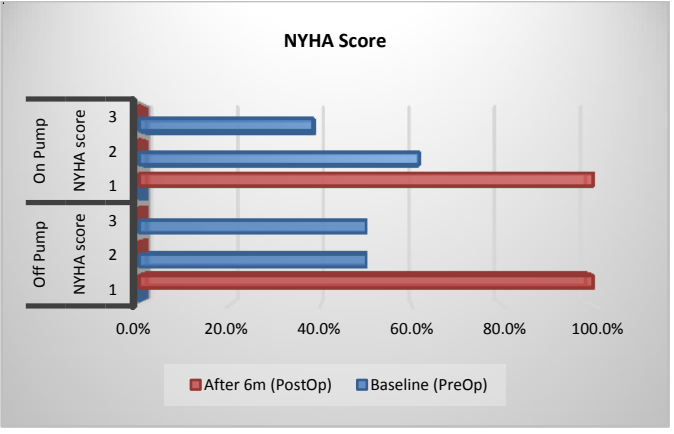

Fig 2: Pre and Post-operative NYHA score in both groups

\begin{tabular}{|c|c|c|c|c|c|c|c|c|}
\hline \multicolumn{3}{|l|}{ Adverse events } & \multicolumn{2}{|c|}{$\begin{array}{l}\text { Off. Group } \\
\mathrm{No}=60\end{array}$} & \multicolumn{2}{|c|}{$\begin{array}{l}\text { On. Group } \\
\mathrm{No}=60\end{array}$} & Chi-Square Test & P Value \\
\hline \multicolumn{3}{|c|}{ Mechanical ventilation (hours) } & \multicolumn{2}{|l|}{$5(4-8)$} & \multicolumn{2}{|c|}{$8.5(4-14)$} & 80.4 & $<0.001$ \\
\hline \multicolumn{3}{|l|}{ ICU stay (hours) } & \multicolumn{2}{|l|}{$36(32-80)$} & \multicolumn{2}{|c|}{$60(37-90)$} & 66.4 & $<0.001$ \\
\hline \multicolumn{3}{|c|}{ Myocardial infarction (MI) } & \multicolumn{2}{|l|}{$3(5 \%)$} & \multicolumn{2}{|c|}{$1(1.7 \%)$} & 1 & 0.309 \\
\hline \multicolumn{9}{|l|}{ Arrhythmia } \\
\hline \multicolumn{3}{|l|}{$\mathrm{AF}$} & \multicolumn{2}{|l|}{$18(30 \%)$} & \multicolumn{2}{|c|}{$10(16.7 \%)$} & \multirow{3}{*}{3.6} & \multirow[t]{3}{*}{0.311} \\
\hline \multicolumn{2}{|l|}{ PVCS } & & \multicolumn{2}{|l|}{$9(15 \%)$} & \multicolumn{2}{|c|}{$14(23.3 \%)$} & & \\
\hline VT & & & \multicolumn{2}{|l|}{$3(5 \%)$} & \multicolumn{2}{|c|}{$4(6.7 \%)$} & & \\
\hline \multicolumn{3}{|l|}{ Stroke } & \multicolumn{2}{|l|}{$1(1.7 \%)$} & \multicolumn{2}{|c|}{$1(1.7 \%)$} & 0.01 & $>0.999$ \\
\hline \multicolumn{3}{|c|}{ Cardiac enzymes (troponin I) } & \multicolumn{2}{|l|}{$8(27 \%)$} & \multicolumn{2}{|c|}{$4(13 \%)$} & \multirow{3}{*}{12} & 0.197 \\
\hline \multicolumn{3}{|c|}{ Mild(less than 5 fold) } & $26(43.3 \%$ & & $32(53$ & & & 0.002 \\
\hline Marked (more than 27 & old) & & $4(6.7 \%)$ & & $14(23$. & & & \\
\hline Renal failure requiring & dialysis & & 0 & & $2(3.3 \%$ & & 2 & 0.154 \\
\hline Elevated liver enzyme & & & 0 & & $31(25$. & & 41.8 & $<0.001$ \\
\hline Exploration for bleedir & & & 0 & & 0 & & 0.0 & $>0.999$ \\
\hline In-hospital mortality & & & 0 & & 0 & & 0.0 & $>0.999$ \\
\hline $\begin{array}{l}\text { Table 5: major posto } \\
\text { compared using Mann } \\
\text { square X2 test. }\end{array}$ & $\begin{array}{l}\text { rative ad } \\
\text { hitney te }\end{array}$ & $\mathrm{e}$ & $\begin{array}{l}\text { mong stu } \\
\text { tative da }\end{array}$ & $\begin{array}{l}\text { d gro } \\
\text { ere e }\end{array}$ & $\begin{array}{l}\text { uanti } \\
\text { ed as }\end{array}$ & $\begin{array}{l}\text { e dat } \\
\text { bers }\end{array}$ & $\begin{array}{l}\text { expressed as } \mathrm{M} \\
\text { centages and cor }\end{array}$ & $\begin{array}{l}\text { an (range } \\
\text { ared using }\end{array}$ \\
\hline & & & bas & & Aft & $6 \mathrm{~m}$ & Wilcoxon & p-value \\
\hline & & & & $\%$ & & $\%$ & test & \\
\hline Off-group & & I & 0 & $0 \%$ & 60 & $100 \%$ & & \\
\hline & NYHA & II & 30 & $50 \%$ & 0 & $0 \%$ & -3.7 & $<0.001$ \\
\hline & & III & 30 & $50 \%$ & 0 & $0 \%$ & & \\
\hline On-group & & I & 0 & $0 \%$ & 60 & $100 \%$ & & \\
\hline & NYHA & II & 37 & $61.7 \%$ & 0 & $0 \%$ & -4.6 & $<0.001$ \\
\hline & & III & 23 & $38.3 \%$ & 0 & $0 \%$ & & \\
\hline
\end{tabular}

Table 6: Postoperative outcomes of studied groups.

\begin{tabular}{|c|c|c|c|c|c|c|c|}
\hline & & \multicolumn{4}{|c|}{ procedure } & \multirow{3}{*}{$\begin{array}{l}\text { Chi- } \\
\text { square }\end{array}$} & \multirow{3}{*}{ p-value } \\
\hline & & Off & $10=60$ & & & & \\
\hline & & $\mathrm{N}$ & $\%$ & $\mathrm{~N}$ & $\%$ & & \\
\hline \multirow[t]{2}{*}{ LIMA to LAD } & $\mathrm{N}$ & 4 & $6.7 \%$ & 6 & $10 \%$ & \multirow[b]{2}{*}{0.4} & \multirow[b]{2}{*}{0.509} \\
\hline & $P$ & 56 & $93.3 \%$ & 54 & $90 \%$ & & \\
\hline \multirow[b]{2}{*}{ LIMA to D } & $\mathrm{N}$ & 57 & $95 \%$ & 55 & $91.7 \%$ & \multirow[b]{2}{*}{0.5} & \multirow[b]{2}{*}{0.464} \\
\hline & $\mathrm{P}$ & 3 & $5 \%$ & 5 & $8.3 \%$ & & \\
\hline \multirow[b]{2}{*}{ SVG to D } & $\mathrm{N}$ & 41 & $68.3 \%$ & 41 & $68.3 \%$ & \multirow[b]{2}{*}{0.01} & \multirow[b]{2}{*}{0.999} \\
\hline & $\mathrm{P}$ & 19 & $31.7 \%$ & 19 & $31.7 \%$ & & \\
\hline \multirow{4}{*}{ SVG to OM } & $\mathrm{N}$ & 15 & $25 \%$ & 16 & $26.7 \%$ & \multirow{4}{*}{0.01} & \multirow{4}{*}{0.998} \\
\hline & $\mathrm{O}$ & 1 & $1.7 \%$ & 1 & $1.7 \%$ & & \\
\hline & $\mathrm{P}$ & 42 & $70 \%$ & 41 & $68.3 \%$ & & \\
\hline & $\mathrm{S}$ & 2 & $3.3 \%$ & 2 & $3.3 \%$ & & \\
\hline \multirow[t]{2}{*}{ SVG to RCA } & $\mathrm{N}$ & 49 & $81.7 \%$ & 43 & $71.7 \%$ & \multirow[b]{2}{*}{1.7} & \multirow[b]{2}{*}{0.195} \\
\hline & $\mathrm{P}$ & 11 & $18.3 \%$ & 17 & $28.3 \%$ & & \\
\hline \multirow[t]{3}{*}{ SVG to PDA } & $\mathrm{N}$ & 21 & $35 \%$ & 19 & $31.7 \%$ & \multirow{3}{*}{0.2} & \multirow{3}{*}{0.927} \\
\hline & $\mathrm{O}$ & 2 & $3.3 \%$ & 2 & $3.3 \%$ & & \\
\hline & $\mathrm{P}$ & 37 & $61.7 \%$ & 39 & $65 \%$ & & \\
\hline \multirow[t]{2}{*}{ SVG to LAD } & $\mathrm{N}$ & 56 & $93.3 \%$ & 54 & $90 \%$ & \multirow[b]{2}{*}{0.4} & \multirow[b]{2}{*}{0.509} \\
\hline & $\mathrm{P}$ & 4 & $6.7 \%$ & 6 & $10 \%$ & & \\
\hline
\end{tabular}

The total number of performed grafts in on-pump group was 185 grafts: two grafts revealed significant stenosis, three grafts showed occlusion. However, off-pump group number of grafts was 177: two grafts showed significant stenosis, three grafts exhibited occlusion. The difference was not statistically significant in revascularization between the two groups after comparing them with multi assessments as the following: number of diseased coronary arteries, number of distal grafts, graft distribution, and postoperative checking of the graft patency after six months using MSCT coronary angiography (Table 7). 
Table 7: post-operative follow up of graft patency by MSCT Angiography after 6 months. Quantitative data were expressed as Median (range) and compared using Mann Whitney test, while qualitative data were expressed as numbers and percentages and compared using Chi-square $\mathrm{X} 2$ test, $\mathrm{N}=$ not done, $\mathrm{P}=$ patent, $\mathrm{O}=$ occlusion, $\mathrm{S}=$ significant stenosis $>50 \%$.

\section{DISCUSSION}

In our study, patients who underwent on-pump CABG had a mean operation time of 242.5 minutes; nevertheless, the off-pump group patients displayed a mean operation time of 186.5 minutes. The statistical difference was highly significant between both groups (P-value < 0.001). Bakaeen et al. (2014) reported that the Mean \pm SD operative time in the onpump group was $6.16 \pm 1.49$ hours; meanwhile, it was $5.77 \pm 1.4$ hours in off-pump group, (P-value < $0.0001)^{6}$

This may be correlated to many reasons, such as waiting for activated clotting time to increase after giving heparin, arterial and venous cannulation, giving cardioplegia and cooling down, rewarm and hot shot, waiting for protamine to antagonize the heparin effect and decannulation.

Shroyer et al. (2009) in ROOBY's study reported that: although the Mean \pm SD operative time onpump group was $4.4 \pm 1.3$ hours, it was $4.5 \pm 1.4$ hours in off-pump group (P-value 0.05 ). This may be due to difficulty of off-pump in compared to onpump as a technique and the experience of the surgeons. ${ }^{7}$

In terms of the intraoperative need for cardiac inotropes in our study, 35 patients $(58.3 \%)$ required inotropes in on-pump group. On the other hand, 6 patients $(10 \%)$ necessitated giving inotropes in offpump group; the statistical difference is deemed highly significant between the two groups (P-value < 0.001). These results come in consistence with Husain et al. (2016) who reported that 123 patients $(82 \%)$ necessitated giving inotropes in on-pump group, whereas only 40 patients $(26.6 \%)$ necessitated inotropes giving in the other group (P-value < $0,0001)^{8}$

This may be correlated to hypotension and arrhythmias following the use of cardioplegia during bypass time and removal of cross clamp, so the heart needs some inotropic support to regain his own rhythm to improve the contractility after weaning from CPB.

In our study regarding the myocardial revascularization in both groups, the total number of grafts were performed in on-pump group was 185 , while in off-pump group it was 177 grafts, Bakaeen et al. (2014) reported that the mean \pm SD number of grafts were performed per each patient was $3.2 \pm 0$, 89 in on-pump group, while it was $2.62 \pm 1.04$ grafts in off-pump group (P-value $<0.0001$ ). In Hussain et al. (2016) $2.9 \pm 0.61$ grafts were performed per each patient in on-pump group while $2.78 \pm 0.68$ grafts in off-pump group (P-value 0.06). Furthermore, in ROOBY's study, $3.0 \pm 1.0$ grafts were performed per each patient in on-pump group, while $2.9 \pm 0.9$ grafts in off-pump group (P-value 0.002). ${ }^{4,6,7,8}$
Regarding the under revascularization, there were $10(16.7 \%)$ patients under revascularized in on-pump group, while there were 13(21.7) patients under revascularized in off-pump group. Also, (ROOBY's study 2011) there were 196 patients $(17.8 \%)$ under revascularized in on-pump group, while 122 patients $(11.1 \%)$ under revascularized in off-pump group (Pvalue $<0.001)^{7}$

This may be correlated to motionless and less bloody field in on-pump CABG.

On the other side, the statistical difference was not significant between the both groups regarding intraoperative bleeding and the use of IABP.

\section{Postoperative Data:}

Regarding the postoperative serial elevation of troponin I and CK-mb in our study, the both enzymes' elevation was significantly higher in the first group (on-pump) than the other group within 6, 12 and 24 hours postoperatively. In Hussain et al. study (2016) the postoperative elevation of CK-mb displayed as mean $\pm \mathrm{SD}$ was $57.69 \pm 38.57 \mathrm{IU} / \mathrm{L}$ in on-pump group, while it was $30.27 \pm 21.85 \mathrm{IU} / \mathrm{L}$, (Pvalue $<0.001)^{8}$

Moreover, Temizturk et al. (2015) reported that troponin release was calculated at 4 hours; it was $5.78 \pm 5.61$ in on-pump group and $0.49 \pm 0.27 \mathrm{ng} / \mathrm{ml}$ in off-pump group (P-value $<0.001)$. At 8 hours, this value was measured as $6.58 \pm 7.97$ in on-pump group and $0.65 \pm 0.34 \mathrm{ng} / \mathrm{ml}$ in off-pump group (P-value < 0.001). At the end of 24th hour, Troponin-I levels were measured as $5.39 \pm 7.72$ in on-pump group and $0.69 \pm 0.75 \mathrm{ng} / \mathrm{ml}$ in off-pump group ( $\mathrm{P}$-value < 0.001 ). These measurements were significantly different when compared to both groups.

Consequently, this elevation may correlate with intra-operative myocardial injury related to pericardium manipulation, cardiac manipulation, inadequate myocardial protection during bypass time, intra-operative defibrillation, or acute post-bypass hemodynamic instability.

In our study, regarding ventilation time, in on-pump group it was between 6 and 14 hours Median (IQR) $8.5(6.0-14.0)$, wheras in off-pump group it was between 4 and 8 hours Median (IQR) 5.0 (4.0-8.0), which is highly statistically significant (p-value 0.001 ). Hussain et al.8 and Tatsuishi $\mathrm{W}$ et al.10 reported that the Mean \pm SD ventilation time was $6.81 \pm 6.97$ hours in on-pump group, while the Mean \pm SD was $5.34 \pm 3.79$ hours in off-pump group (Pvalue 0.025 ).

On the other hand, in ROOBY's study it was reported that the Mean $\pm \mathrm{SD}$ ventilation time was $15.8 \pm 40.3$ hours in on-pump group, and it was 17.1 \pm 36.5 hours in off-pump group, (P-value 0.43$)^{7}{ }^{7}$ 
This may be correlated with the decrease in operative time, low doses of cardiac inotropes, decrease amount of blood loss which means more hemodynamic stability in off-pump group leading to early ex-intubation.

In this study, concerning the duration of ICU stay, in on-pump group, it was ranging between 37 and 90 hours Mean 60, while it was ranging between 32 and 80 hours Mean 36 in off-pump group; this is deemed as highly statistically significant ( $\mathrm{p}$-value $<0.001$ ).

Hussain et al. ${ }^{8}$ (2016) reported that the Mean \pm SD of ICU stay was $42.67 \pm 23.44$ hours in on-pump group; meanwhile, the Mean \pm SD was $35.02 \pm 12.15$ hours in off-pump group, (P-value 0.001).

On the contrary, ROOBY's study reported that the Mean \pm SD of ICU stay in on-pump group was $3.8 \pm$ 4.0 days, however, the Mean $\pm \mathrm{SD}$ was $3.7 \pm 3.8$ days in off-pump group (P-value 0.69). ${ }^{7}$

This may be attributed to early ex-intubation so early ambulation and lower need to cardiac inotropes than on-pump CABG.

Furthermore, statistical difference was not significant between the two groups in terms of new onset myocardial infarction, cardiac arrhythmia, cerebrovascular stroke, wound infection, ECG changes, use of IABP, renal failure requiring dialysis, postoperative bleeding requiring re-exploration, and mortality.

The assessment of the intra operative graft patency of both groups revealed statistically significant difference between them. All TTFM readings of offpump group displayed approximately a $15-25 \%$ increase more than the on-pump group. After revision of grafts, it is clear that more TTFM assessment is needed for off-pump group more than on-pump group. Between April 2015 and December 2017, the REQUEST (2018) study-which is multicenter, international, and prospective registryrecruited 1046 patients in 7 facilities regularly performing CABG in Europe (n $1 / 4$ 4) and North America (n $1 / 43)$; it found that $25 \%$ of cases required TTFM modification. ${ }^{11}$

Cases may fulfill a great outcome with either technique, and their outcomes are likely to be determined by variables other than whether they had traditional $\mathrm{CABG}$ or OPCAB. Nonetheless, most studies tend to exhibit trends. After OPCAB, there are reported decreases in the following: blood loss and the requirement for transfusions, myocardial enzyme production up to 24 hours, less early neurocognitive impairment, and less renal insult; all of these are examples of these trends. Moreover, when compared to normal $\mathrm{CABG}, \mathrm{OPCAB}$ requires less grafts. The two groups seem to have comparable length of hospital stay, death rates, and long-term neurological and cardiac outcomes. ${ }^{12}$

\section{CONCLUSION}

Off-pump CABG is easy to use and helps lowering the incidence of postoperative complication related to cardiopulmonary bypass; furthermore, it decreases hospital stay, cost, and morbidity. However, excellent results can be obtained with both techniques when done by expert hands.

\section{REFERENCES}

1. Filardo G, Hamman BL, da Graca B, et al. Efficacy and effectiveness of on- versus offpump coronary artery bypass grafting: A metaanalysis of mortality and survival. $J$ Thorac Cardiovasc Surg. 2018;155(1):172-9.

2. Sellke FW, DiMaio JM, Caplan LR, et al. Comparing on-pump and off-pump coronary artery bypass grafting: numerous studies but few conclusions: a scientific statement from the American Heart Association council on cardiovascular surgery and anesthesia in collaboration with the interdisciplinary working group on quality of care and outcomes research. Circulation. 2005;111(21):2858-64.

3. Grover FL. Current status of off-pump coronaryartery bypass. $N$ Engl J Med. 2012; 366(16):1541-7.

4. Bakaeen FG, Shroyer AL, Gammie JS, et al. Trends in use of off-pump coronary artery bypass grafting: Results from the Society of Thoracic Surgeons Adult Cardiac Surgery Database. $J$ Thorac Cardiovasc Surg. 2014;148(3):856-3, 864.

5. Mate R, Shaikh N, Raut C, et al. Comparison of prophylactic levosimendan versus intra-aortic balloon pump for off-pump coronary artery bypass grafting in patients with low ejection fraction: A randomized-controlled trial. Cardiovasc Surg Int. 2020;7(3):121-8.

6. Bakaeen FG, Chu D, Kelly RF, et al. Perioperative outcomes after on and off-pump coronary artery bypass grafting. Texas Heart Institute Journal. (2014);41(2): 144-51.

7. Shroyer AL, Grover FL, Hattler B, et al. Onpump versus off-pump coronary-artery bypass surgery. New England Journal of Medicine. 2009;361(19):1827-37.

8. Hussain G, Azam H, Baig MA, et al. Early outcomes of on-pump versus off-pump Coronary Artery Bypass Grafting. Pakistan Journal of Medical Sciences. 2016;32(4): 917.

9. Temizturk Z, Azboy D, Karapınar K, et al. The Comparison of Clinical and Biochemical Outcomes in Off-Pump and Conventional Coronary Artery Bypass Grafting Surgery. Open Access Library Journal. 2015; 2(08):1. 
10. Tatsuishi W, Sato T, Kataoka G, et al. High-flow nasal cannula therapy with early extubation for subjects undergoing off-pump coronary artery bypass graft surgery. Respir Care. 2020; 65(2):183-90.

11. David P, Taggart, Daniel JM, et al. Intraoperative transit-time flow measurement and highfrequency ultrasound assessment in coronary artery bypass grafting. $J$ Thoracic Cardiovascular Surgery. 2020; 159:1283-92.

12. Sellke FW, DiMaio JM, Caplan LR, et al. Comparing on-pump and off-pump coronary artery bypass grafting: numerous studies but few conclusions: a scientific statement from the American Heart Association council on cardiovascular surgery and anesthesia in collaboration with the interdisciplinary working group on quality of care and outcomes research. Circulation. 2005; 111(21):2858-64. 